\title{
Gender Role Perception, Empathic Tendency, and Resilience in Predicting Life Satisfaction among Turkish University Students
}

\author{
Research Article \\ Metehan CELIK ${ }^{1}$ \\ ${ }^{1}$ Çukurova University, Faculty of Education, Department of Educational Sciences, Adana, Turkey, ORCID: 000-0001-7739-5571
}

To cite this article: Celik, M. (2021). Gender role perception, empathic tendency, and resilience in predicting life satisfaction among Turkish university students, International Online Journal of Educational Sciences, 13(4), 1254-1268.

\begin{tabular}{|c|c|}
\hline ARTICLE INFO & ABSTRACT \\
\hline Article History: & $\begin{array}{l}\text { This study aimed to investigate whether gender role perception, empathic tendency, and resilience } \\
\text { of Turkish university students are indicators of their life satisfaction in terms of their genders. Using }\end{array}$ \\
\hline Received: 14.04.2021 & $\begin{array}{l}\text { the Satisfaction with Life Scale, the Gender Socialization Scale, the Empathic Tendency Scale, and the } \\
\text { Adult Psychological Resilience Scale, we collected data from } 336 \text { female and } 123 \text { male students. Data }\end{array}$ \\
\hline $\begin{array}{l}\text { Available online: } \\
\text { 13.07.2021 }\end{array}$ & $\begin{array}{l}\text { analysis revealed that males had significantly higher traditional gender perceptions than females, } \\
\text { whereas females had significantly higher empathic tendency, resilience, and life satisfaction levels. }\end{array}$ \\
\hline & $\begin{array}{l}\text { We concluded that, resilience, empathic tendency, and traditional gender perception explained life } \\
\text { satisfaction scores of the students. The order of importance of predictive variables on life satisfaction } \\
\text { was resilience, empathic tendency, and traditional gender perception. The multiple regression } \\
\text { analysis showed that three variables significantly contributed to life satisfaction in general. The order } \\
\text { of relative importance of predictive variables for life satisfaction was resilience, empathic tendency, } \\
\text { and traditional gender role perception. }\end{array}$ \\
\hline
\end{tabular}

(C) 2021 IOJES. All rights reserved

Keywords:

Social gender, life satisfaction, resilience, empathic tendency, university student.

\section{Introduction}

University life is an important stage in many peoples' lives, in which a series of complex, sensitive, personal, emotional, social, and professional changes arise. At college, they must adapt not only to the universal sociocultural environment of the university such as personality, interpersonal relationships, professional identity, working skills, adaptation to values, beliefs and a new perspective of life, but also to universal socio-cultural environment (Cabras and Mondo 2018; Park and Adler 2003; Mudhowozi 2012). Students generally delay joining university in Turkey due to a variety of reasons, such as an obligation to

\footnotetext{
${ }^{1}$ Corresponding author's address: Çukurova Üniversitesi 
work, the struggle to make a living, gender, and gender roles. These conditions can lead to pressure, stress, and low life satisfaction (Melman, Little and Akin-Little, 2007; Ünsal-Barlas, Karaca, Onan and Iş1l, 2010). While this situation results in a different difficulty and stress for students, adaptation process after starting the university might also affect their stress levels, psychological well-being, and life satisfaction. Studies conducted in this field have emphasized that there might be differences in the adaptation to the environment in terms of gender characteristics, but traditional gender attitudes might lead to more negative situations (Moradi and Subich 2002; Martin, Swartz, Kulstad and Maldson 1999). Males can adapt to university life more quickly than females. The environment in which girls and boys were raised, and the attributes of gender might affect adaptation to the new environment (Yau and Chang 2014). Individuals who were raised with traditional gender roles and the ones who were raised with egalitarian gender roles are different in terms of their coping skills, ability to adapt, and psychological well-being (Keith 2007; Quimby and O'Brien 2006). The traditional gender roles of the society in which an individual grew up might also affect their potential for coping with problems (Myers and Mobley 2004; Schuetze and Slowey 2002). When students first step into university life, they might start with high stress and low motivation, and they have to fulfill the academic demands of the university. Being able to overcome the problems depends on the students' systematic use of coping strategies, and this can increase their academic stress levels and life satisfactions (Skinner and Zimmer-Gembeck 2007). In addition, individuals who were raised with traditional gender roles may feel confusion when presented with the egalitarian gender role attitudes common in university environments. Previous studies have shown that life satisfaction levels may decrease when experiencing a role conflict while performing egalitarian gender role behaviors although they have ideal and traditional role expectations (Gui 2019; Perrewe and Hochwarter 2001; Grant-Vallone and Donaldson 2001). Traditional gender roles are directly correlated with the psychological well-being levels of individuals. When the relationship between life satisfaction, which is a predictor of psychological well-being, and gender roles are considered, traditional gender roles between females and males reveal the discrimination and this reduces the life satisfaction levels of individuals (van de Vijver 2007). Buchanan and Selmon (2008) investigated the differences between traditional and egalitarian gender roles of university undergraduates, and they concluded that there is a positive relationship between self-efficacy/life satisfaction and an egalitarian attitude. Popham, Hunt, Benzeval, Bhaskar and Sweeting (2014) expressed that psychological stress was particularly higher among males who had more traditional gender role attitudes.

Empathic tendency is one of the factors related to life. Empathy is described as feeling and sharing the emotions that are being experienced by another person. Empathic skills are an important factor, especially in socializing, and individuals with empathic strength have higher motivation levels and a higher willingness to socialize and communicate with others. All of these positively influence their life satisfaction levels (Terri and Chan 2014). Empathy is an important personality trait that reflects emotional and social functioning. Understanding others' emotions and being able to build cognitive empathy are considered important in finding out the reasons for others' actions (Jolliffe and Farrington 2006; Errasti, Vázquez, Villadangos and Morís 2018). In addition to being a source of psychological well-being, empathy is effective in increasing life satisfaction. People with high empathic tendency experience less anxiety, worry, and negative feelings about problems (Barnard and Curry 2012; Neff 2009). When theoretical research about empathy is considered, it is expressed that human beings have an innate empathic tendency, and this kind of tendency constitutes the environment that is really important in human development and empathy makes the society more tactful (De la Fuente-Anuncibay, Gonza'lezBarbadillo, Gonza'lez-Bernal, Cubo and PizarroRuiz 2019; Spreng, McKinnon, Mar and Levine 2009). Empathic tendency is investigated by researchers in relation to many psychological variables. It is indicated that individuals who have ideas, such as empathy, about themselves and showing compassion to themselves by understanding emotionally are at a positive level in terms of psychological health (Neff, Kirkpatrick and Rude 2007; Allen, Goldwasser and Leary 2012; Wasylkiw, 
MacKinnon and MacLellan 2012). Moreover, it is supported that empathy has a positive relationship with psychological structures, such as life satisfaction, happiness, optimism, and emotional flexibility (Neff, Hsieh and Dejittera 2005; Leary, Tate, Adams, Allen and Hancock 2007).

Resilience, also known as "stress resistant attitude," is defined as the ability to adapt to and cope with stressful and difficult situations (Liu, Reed and Girard 2017; Jenkins 2016). Furthermore, studies state that life satisfaction correlates with many psychological characteristics, and there is an essential relationship between resilience and life satisfaction (Redersstorff, Buchanan and Settles 2007; Tepeli-Temiz and Tari-Cömert 2018). Resilience refers to an individual's ability to fight against difficulties and improve (Luthar, Cicchetti and Becker 2000; Connor and Davidson 2003). Resilience of an individual is also connected with physical and mental health. An individual who has high psychological resilience is able cope with trauma following stress better (Connor and Davidson 2003; Bonanno 2004). Resilience, which is considered a positive psychological structure, is believed to play an important role in increasing life satisfaction (Gable and Haidt 2005). Life satisfaction refers to the cognitive evaluation of individuals being happy with their lives (Diener, Oishi and Lucas 2003). Numerous studies have shown that psychological resilience is related to a high level of life satisfaction (Cohn, Fredrickson, Brown, Mikels and Conway 2009; Hu, Zhang and Wang 2015; Mak, Ng and Wong 2011).

While previous studies have evaluated the relationship between one or two of the variables included in this research, we have found no studies investigating these variables together. This study aims to investigate the role of egalitarian and traditional gender perception, empathic tendency, and psychological resilience on the life satisfaction of Turkish university students. For the present research, This study has been formulated the following research questions:

- Does the relationship between life satisfaction of university students and their gender role perception, empathic tendency, and resilience differ according to gender?

- Do gender role perception, empathic tendency, and resilience levels of university students predict their life satisfaction levels?

- Do gender role perception, empathic tendency, and resilience levels of university female students predict their life satisfaction levels?

- Do gender role perception, empathic tendency, and resilience levels of university male students predict their life satisfaction levels?

\section{Method}

\section{Participants}

This study was conducted with students at Çukurova University, located in the province of Adana, in the Mediterranean Region of Turkey. Participants included 336 females (73\%) and 123 males (27\%). The mean age was $21.07(\mathrm{SD}=2.43)$ for the females, and $21.37(\mathrm{SD}=1.60)$ for the males. The participants were selected randomly and answered the scales voluntarily.

\section{Scales}

The Satisfaction with Life Scale (SWLS). We used the SWLS scale to measure the life satisfaction level of the participants. This scale was developed by Diener, Emmons, Larsen and Griffin (1985), and it was translated into Turkish by Köker (1991). The scale uses a 7-point Likert-type scale and it consists of a single dimension and 5 items. The highest score is 5 and the lowest is 35 . Higher scores indicate high life satisfaction 
levels. The test-retest reliability of the scale was found to be .85 , and item test correlations were between .71 and .80 .

The Gender Socialization Scale. The scale was developed by Epstein (2008). The original form of the scale consisted of five dimensions (traditional gender roles, egalitarian gender roles, toughness, being nice and pleasant, and body consciousness) and 23 items. The Turkish version of the scale is by Arıc1 (2011), and it consists of two sub-dimensions and 19 items. The first dimension is named "Traditional Gender Roles" and the second dimension is named "Egalitarian gender roles." Cronbach's alpha internal consistency coefficient was determined to be .79 for "traditional gender roles" and .63 for "egalitarian gender roles." Test-retest reliability coefficient of the scale was .80 for "traditional gender roles" and .86 for "egalitarian gender roles." The responses are rated on a 4-point Likert-type scale. Moreover, the highest score that can be received from the scale is 15 for the egalitarian roles and 42 for the traditional roles.

The Empathic Tendency Scale (ETS). The scale was developed by Dökmen (1988) to measure the emotional component of empathy and empathy potential of an individual in daily life. Some items of the ETS reflect the characteristics of egocentric communication. The ETS is a Likert-type scale, and there are 20 questions which are scored between 1 and 5. The lowest possible score is 20, and the highest is 100. Higher scores show that empathic tendency is high, and low scores show that empathic tendency is low. Test-retest reliability coefficient of the scale was found to be .82 , and split-half test reliability was found to be .86 . Cronbach's alpha was determined as .72. Regarding the criterion-related validity study of the ETS, the validity of the relationship between the scores from the "Understanding Feelings" section of Edwards Personal Preference Inventory was found 0.68.(Dökmen 1988).

The Adult Psychological Resilience Scale. The scale was adapted to Turkish by Arslan (2015), to measure the adult psychological resilience. The measurement tool, which has a five-point Likert structure, is ranked between "It completely identifies me (5)" and "It never defines (1)". Besides the scale consists of four sub-dimensions, and the adult resilience measure and its subscales can be used to assess resilience in adults. A high score indicates a high level of psychological resilience. Internal consistency and test-retest values were examined in the scope of reliability study of the adult psychological stability scale. Cronbach's alpha was .94. Test-retest coefficient was calculated as .85. It was found that internal consistency of the scale changed between .82 and .86 , and test-retest coefficient changed between .64 and .79. In the scope of the criterion validity of the scale, life satisfaction scale, positive-negative feeling scale, and Rosenberg self-esteem scale were used. Psychological stability has significant relationships with life satisfaction at the level of .50, positive feelings at the level of .40, negative feelings at the level of .33, and self-esteem at the level of .42 (Arslan 2015).

\section{Data Analysis}

In order to understand whether the data is distributed normally or not, we checked skewness and kurtosis values of the data. According to the findings, skewness coefficient of the data was determined to be .68 , and the kurtosis coefficient of the data was determined to be -.43. Kline (2011) supports the idea that distributions are considered normal if the skewness coefficient is smaller than |3.0| and kurtosis coefficient is smaller than $\mid 10.0 \mathrm{I}$. As the data of the research was distributed normally, parametric tests (MANOVA, Pearson's product-moment correlation analysis, and multiple regression analysis) were used in the following analysis. After obtaining the mean scores of the items in the research, correlation coefficients were checked to determine whether the mean scores show a relationship between the variables. In addition, histogram and normality assumptions of the data were examined, and they were found to be satisfactory. Analysis was carried out with SPSS version 22.0.

\section{Results}

Differences in life satisfaction, social gender, empathic tendency, and resilience according to gender; 
MANOVA was performed to evaluate the differences in life satisfaction, social gender, empathic tendency, and resilience. The results show that there was a significant difference according to gender. The differences in egalitarian gender perception, traditional gender perception, empathic tendency, resilience, and life satisfaction levels were evaluated through MANOVA. Equality of variance was acceptable based on Box's $\mathrm{M}$ (Box's M=17.74; F=1.75, p>.05) MANOVA results of analysis revealed that there were significant differences according to gender in respect to traditional gender perception, emphatic tendency, resilience, and life satisfaction (Wilk's Lambda $(\Lambda)=0.938, \mathrm{~F}(1,457)=7.55, \mathrm{p}<.001)$.

It shows one-way ANOVA factor results depending on life satisfaction, social gender, empathic tendency, resilience, gender, means, and standard deviations of the variables. As seen in Table 1, males had significantly higher traditional gender perception ( $\mathrm{F}=16.99, \mathrm{p}<.001)$, and females had significantly higher empathic tendencies $(\mathrm{F}=14.41, \mathrm{p}<.001)$, resilience $(\mathrm{F}=8.43, \mathrm{p}<.001)$, and life satisfaction levels $(\mathrm{F}=4.47, \mathrm{p}<.05)$.

Table 1. F results of MANOVA depending on gender

\begin{tabular}{lccccccc}
\hline & Gender & $\mathbf{n}$ & $\mathbf{X}$ & SD & df & F & p \\
\hline \multirow{2}{*}{ Egalitarian gender perception } & $\mathrm{M}$ & 123 & 16.32 & 2.78 & & & \\
\hline \multirow{2}{*}{ Traditional gender perception } & $\mathrm{F}$ & 336 & 16.17 & 3.30 & $1-457$ & .20 & .655 \\
\hline \multirow{2}{*}{ Empathic tendency } & $\mathrm{F}$ & 123 & 37.08 & 7.61 & & & \\
\hline \multirow{2}{*}{ Resilience } & $\mathrm{M}$ & 123 & 67.48 & 8.52 & & & \\
\hline & $\mathrm{F}$ & 336 & 70.80 & 8.19 & $1-457$ & 14.41 & $.000^{* *}$ \\
Life satisfaction & $\mathrm{M}$ & 123 & 81.47 & 10.52 & & & \\
\hline
\end{tabular}

Note: M: Male, F: Female, ${ }^{*} \mathrm{p}<.05,{ }^{* *} \mathrm{p}<.001$

\section{The relationship between life satisfaction, social gender, empathic tendency, and resilience}

When the bivariate partial correlation between the predictor variables and the dependent variable was considered, it was determined that there was a positive significant relationship between egalitarian gender perception and life satisfaction $(\mathrm{r}=.12, \mathrm{p}<.001)$, a negative significant relationship between traditional gender perception and life satisfaction $(\mathrm{r}=-.19, \mathrm{p}<.001)$, a positive significant relationship between empathic tendency and life satisfaction $(\mathrm{r}=.40, \mathrm{p}<.001)$, and a positive significant relationship between resilience and life satisfaction $(\mathrm{r}=.43, \mathrm{p}<.001)$. The relationship between female's life satisfaction, gender perceptions, empathic tendency, and resilience When the bivariate partial correlation between the predictor variables and the dependent variable was considered, it was determined that there was a positive significant relationship between empathic tendency and life satisfaction $(\mathrm{r}=.40, \mathrm{p}<.001)$, and a positive significant relationship between resilience and life satisfaction $(\mathrm{r}=.46, \mathrm{p}<.001)$, a positive relationship between egalitarian gender perception and life satisfaction $(\mathrm{r}=.10, \mathrm{p}<.001)$, a negative significant relationship between traditional gender perception and life satisfaction $(\mathrm{r}=-.17, \mathrm{p}<.001)$. The relationship between male's life satisfaction, gender perceptions, empathic tendency, and resilience When the bivariate partial correlation between the predictor variables and the dependent variable was considered, it was determined that there was a positive significant relationship between empathic tendency and life satisfaction $(\mathrm{r}=.35, \mathrm{p}<.001)$, and a positive significant relationship between resilience and life satisfaction ( $\mathrm{r}=.35, \mathrm{p}<.001)$, a positive relationship between egalitarian gender perception and life satisfaction $(\mathrm{r}=.17, \mathrm{p}<.001)$, a negative significant relationship between traditional gender perception and life satisfaction $(\mathrm{r}=-.19, \mathrm{p}<.001)$. 
Table 2. Correlations of predictor and criterion variables for total sample, female and male

\begin{tabular}{|c|c|c|c|c|c|c|}
\hline Whole sample & $\mathbf{M}$ & SD & 1 & 2 & 3 & 4 \\
\hline \multicolumn{7}{|l|}{ Predicted Variable } \\
\hline Life satisfaction & 23.0283 & 5.92431 & .118 & $.397^{* * *}$ & $.432^{* * *}$ & $-.187^{* * *}$ \\
\hline \multicolumn{7}{|l|}{ Predictor Variables } \\
\hline 1. Egalitarian gender perception & 16.2157 & 3.16905 & - & .075 & $.257^{* * *}$ &.-044 \\
\hline 2. Empathic tendency & 69.9150 & 8.40796 & - & - & $.484^{* * *}$ & $-.183^{* * *}$ \\
\hline 3. Resilience & 83.8214 & 10.53724 & - & - & - & -.094 \\
\hline 4. Traditional gender perception & 34.5185 & 8.19849 & - & - & - & - \\
\hline \multicolumn{7}{|l|}{ Female } \\
\hline Predicted Variable & $\mathrm{M}$ & SD & 1 & 2 & 3 & 4 \\
\hline Life satisfaction & 23.3810 & 5.69138 & $.402^{* * *}$ & $.458^{* * *}$ & .105 & $-.167^{* * *}$ \\
\hline \multicolumn{7}{|l|}{ Predictor Variables } \\
\hline 1.Empathic tendency & 70.8036 & 8.19957 & - & $.477^{* * *}$ & $.078^{* *}$ & $-.128^{* * *}$ \\
\hline 2.Resilience & 84.6786 & 10.03238 & - & - & .277 & -.080 \\
\hline 3.Egalitarian gender perception & 16.1756 & 3.30203 & - & - & - & -.099 \\
\hline 4. Traditional gender perception & 33.5804 & 8.21572 & - & - & - & - \\
\hline \multicolumn{7}{|l|}{ Male } \\
\hline Predicted Variable & $\mathrm{M}$ & SD & 1 & 2 & 3 & 4 \\
\hline Life satisfaction & 22.0650 & 6.44490 & $.355^{* * *}$ & $.355^{* * *}$ & .170 & -.188 \\
\hline \multicolumn{7}{|l|}{ Predictor Variables } \\
\hline 1.Empathic tendency & 67.4878 & 8.52419 & - & $.461^{* * *}$ & $.086^{* *}$ & $-.232^{* * *}$ \\
\hline 2.Resilience & 81.4797 & 11.52855 & - & - & .230 & -.046 \\
\hline 3.Egalitarian gender perception & 16.3252 & 2.78313 & - & - & - & .127 \\
\hline 4. Traditional gender perception & 37.0813 & 7.61211 & - & - & - & - \\
\hline
\end{tabular}

${ }^{*} \mathrm{p}<.05,{ }^{* *} \mathrm{p}<.01,{ }^{* * *} \mathrm{p}<.001$

The results of stepwise regression analysis of the research are presented in Table 3. Egalitarion gender perception, traditional gender perception, empathic tendency, and resilience explain the students' life satisfaction scores significantly. This explains $24 \%$ of the total variance in the life satisfaction scores together with the given predictors of the research $\mathrm{F}(3-56)=29.066$. When considering the results, the relative significance order of the predictors on life satisfaction are resilience $(\beta=.321, \mathrm{p}<.001)$, empathic tendency $(\beta=.284, \mathrm{p}<.001)$, and traditionalist gender perception $(\beta=.126, \mathrm{p}<.001)$, according to the standardized regression coefficients $(\beta)$ for the whole sample. When considering t-test results about the significance of regression coefficients, resilience $(t=6.36, p<.001)$, empathic tendency $(t=5.85, p<.001)$, and traditional gender perception $(t=3.01, p$ $<.001)$ are significant predictors for life satisfaction.

As presented in Table 3, the results of the multiple regression analysis show that three variables significantly contributed to life satisfaction of females. According to the standardized regression coefficients $(\beta)$, the relative significance order of the predictors of life satisfaction are resilience $(\beta=.348, p<.001)$, empathic tendency $(\beta=.224, \mathrm{p}<.001)$, and traditional gender perception $(\beta) .=-.133, \mathrm{p}<.05)$. When considering $\mathrm{t}$-test results about the significance of regression coefficients, resilience $(t=6.24, p<.001)$, empathic tendency $(t=$ $4.13, \mathrm{p}<.001)$, and traditional gender perception $(\mathrm{t}=-2.36, \mathrm{p}<.001)$ are significant predictors for life satisfaction. Predictor variables consisted of $27 \%$ of total variance $\mathrm{F}(3-56)=29.96, \mathrm{p}<.001$. Moreover, the results of a multiple regression analysis showed that four variables significantly not to contributed to life satisfaction of males. The predictor variables constituted $20 \%$ of the total variance $F(3-56)=7.41, p<.001$. According to the standardized regression coefficients $(\beta)$, the relative significance order of the predictors for life satisfaction are resilience $(\beta=.225, \mathrm{p}>.001)$, empathic tendency $(\beta=.207, \mathrm{p}>.001)$ traditional gender role perception $(\beta=-.145$, $\mathrm{p}>.001)$ and egalitarian gender role perception $(\beta=-.119, \mathrm{p}>.001)$. 
Table 3. The results of multiple regression analysis about the prediction of life satisfaction

\begin{tabular}{|c|c|c|c|c|c|c|c|}
\hline Whole sample & B & SEв & Beta & $\mathbf{t}$ & $\mathrm{p}$ & $\mathbf{R}^{2}$ & $\mathbf{R}^{2}$ change \\
\hline \multicolumn{8}{|l|}{ Predicted Variable } \\
\hline Life satisfaction & 55.766 & 4.994 & - & .819 & .000 & - & - \\
\hline \multicolumn{8}{|l|}{ Predictor Variables } \\
\hline Resilience & .316 & .050 & .321 & 6.360 & .000 & .286 & .239 \\
\hline Empathic tendency & .352 & .060 & .284 & .5 .855 & .000 & .265 & .123 \\
\hline Traditional gender perception & .160 & .053 & .126 & 3.010 & .003 & .140 & .260 \\
\hline Egalitarian gender perception & .114 & .139 & .035 & .819 & .413 & .038 & .033 \\
\hline $\mathrm{R}=0.493$ & \multicolumn{3}{|c|}{ Adjusted $R^{2}=.235$} & $(3-56)=29.066$ & \multicolumn{2}{|c|}{$\mathrm{p}=.000$} & \\
\hline Female & B & SEв & Beta & $\mathrm{t}$ & $\mathrm{p}$ & $\mathrm{R}^{2}$ & $\mathrm{R}^{2}$ change \\
\hline \multicolumn{8}{|l|}{ Predicted Variable } \\
\hline Life satisfaction & -1.122 & 3.177 & - & -.353 & .724 & - & - \\
\hline \multicolumn{8}{|l|}{ Predictor Variables } \\
\hline Resilience & .197 & .032 & .348 & 6.240 & .000 & .324 & .294 \\
\hline Empathic tendency & .155 & .038 & .224 & 4.137 & .000 & .222 & .195 \\
\hline Traditional gender perception & -.078 & .033 & -.113 & -2.361 & .019 & -.129 & -.111 \\
\hline Egalitarian gender perception & -.035 & .085 & -.020 & -.415 & .679 & -.023 & -.020 \\
\hline $\mathrm{R}^{2}=.201$ & \multicolumn{3}{|c|}{ Adjusted $R^{2}=.174$} & $(3-56)=7.412$ & \multicolumn{2}{|c|}{$\mathrm{p}=.000$} & \\
\hline Male & $\mathrm{B}$ & SEв & Beta & $\mathrm{t}$ & $\mathrm{p}$ & $\mathrm{R}^{2}$ & $R^{2}$ change \\
\hline \multicolumn{8}{|l|}{ Predicted Variable } \\
\hline Life satisfaction & 1.297 & 6.172 & - & .210 & .834 & - & - \\
\hline \multicolumn{8}{|l|}{ Predictor Variables } \\
\hline Resilience & .126 & .053 & .225 & 2.370 & .019 & .213 & .195 \\
\hline Empathic tendency & .156 & .072 & .207 & 2.167 & .32 & .196 & .178 \\
\hline Traditional gender perception & -.123 & .073 & -.145 & -.1 .692 & .093 & -.154 & -.139 \\
\hline Egalitarian gender perception & .276 & .198 & .119 & 1.393 & .166 & .127 & .115 \\
\hline $\mathrm{R}^{2}=.266$ & \multicolumn{3}{|c|}{ Adjusted $R^{2}=.257$} & $F_{(3-56)}=29.969$ & \multicolumn{2}{|c|}{$\mathrm{p}=.000$} & \\
\hline
\end{tabular}

\section{Discussion}

This study aims to investigate whether life satisfaction, gender perception, empathic tendency, and resilience differ with regards to gender. In the study, it was determined that the traditional gender perception scores of the males were higher than the females in terms of gender while the traditional gender perception scores of the females were lower. Gender is an important predictor variable for gender role perception. Even if it is accepted that the reflections of biological gender characteristics of individuals who act in accordance with traditionally performed gender roles in societies are an indicator of their psychological and mental health, there is a lack of empirical evidence (DiDonato and Berenbaum 2013). In addition, strict adherence to traditional masculine and feminine roles may be a challenge in affirming non-traditional gender roles, which can affect life satisfaction considerably (Parent and Moradi 2010). In this study, low traditional gender role scores of the females may be caused by the pressure imposed by the society in which the girls live. An increase in a families' socio-economic status, the spouses' educational status, females' having a job, a companionate marriage, and females' contribution to the family budget are indicators of a change in gender roles in the direction of egalitarian in the contemporary societies. Such changes are discussed in countries like Turkey, which may be the cause of high egalitarian gender perception scores (İmamoğlu 1994). Traditional female roles in Turkey cause a pressure together with taking away the females' social, economic, and humanitarian rights together constitute an edition. The willingness to acquire some rights due to this pressure may have resulted in a right to have a more egalitarian life. Furthermore, the need to build a balance between these two 
situations in a society where family expectations change and different family roles become important with the transition to contemporary family life and the desire of all individuals and especially females in the family create resource for the increase in the egalitarian gender scores (Eken 2006). This study shows differences in the empathic tendency levels of females and males, which is in accordance with findings from previous studies, in which females were shown to have higher empathic levels than males (Preti, Vellante, Baron-Cohen, Zucca, Petretto and Masala 2011; Chen, Feng, LV, LU, 2018). This result of the study may be derived from Turkish parents' raising their children according to traditional gender roles. Families raise their daughters more emotionally and sensitively. In addition, different socialization of females and males, acquisition and development of feminine and masculine roles still continue. Although it seems that there have been some changes in the last few years, society and media still encourage males embody traditional masculinity traits, and for females to have traditional values in general (Dökmen 2012). Therefore, sensitivity, which is one of the traditional gender roles of females, can be effective in high empathic tendency.

Another finding of the study is that resilience scores of the females were higher. Social support network in Turkish society has a wider scope when it is considered from the point of females. Females interact more with units that provide socialization, such as family, relatives, and neighbors. The support that they get from these units can help females cope with pressure and stressors, and have better resilience. Previous literature supports this finding (Caetano, Silva and Vettore 2013; Zhang, Zhang, Zhang, Zhang and Feng 2018). Moreover, the studies express that social support promotes both physical and psychological health and increases the power of endurance (Nickerson and Nagle 2004; Uchino, Cacioppo and Kiecolt-Glaser 1996).

Various studies have shown that social gender is an important variable that predicts life satisfaction (Matud, Bethencourt and Ibáñez 2014; Myers 2000). Previous studies have also shown that males tend to adopt traditional gender roles, and females more often adopt non-traditional gender roles (Kimberly and Mahaffy 2002; Trommsdorff and Iwawaki 1989; Keith and Jacqueline 2002). In this study, the perception of traditional gender roles was found to be an important predictor in males' social gender perceptions. Previous studies that point out the significant differences between females and males in terms of life satisfaction (Glaesmer, Grande, Braehler and Roth 2011; Ng, Loy, Gudmunson and Cheong 2009; Salinas-Jiménez, Artés and Salinas-Jiménez 2013), which is consistent with the findings of the present study. The present study is also consistent with previous findings that males' life satisfaction levels are higher than females' (Jacobsen, Lee, Marquering and Zhang 2014; Goldbeck, Schmitz, Besier, Herschbach and Henrich 2007; Cabras and Mondo 2017). Additionally, previous research states that females' life satisfaction might be higher than males' (Kamphampati, Giusta and Jewel 2011; Oshio 2012). Life satisfaction might be affected by conditions specific to a person's culture, and distinct differences in business life, social life, marriage, and family life might affect psychological changes, life happiness, and self-esteem (Chui and Wong 2016). Traditional pressure still continues for females and males to socialize differently, acquire different skills, and take on different roles. As a consequence, different life satisfaction scores of females and males and high life satisfaction scores of males in this study may be derived from the sustainability of traditional gender roles. Another finding of this study is that females have more empathic tendency than males. Studies about life satisfaction express that empathy has an important role and predictive power on life satisfaction, and there is a positive relationship between two variables (Caro, San-Martín, Delgado-Bolton and Vivanco 2017; Choi, Minote, Sekiya and Watanuki 2016; Bourgault, Lavoie, Paul-Savoie, Grégoire, Michaud, Gosselin and Johnston 2015). Previous studies have shown that empathic tendencies of males are lower than of females (Erçoban 2003; Karakaya 2001; Solak 2011; Duru 2002; Rehber and Atıc1 2009). In this study, the main reason for the difference in the empathic tendency levels in terms of gender can be considered as the girls' being directed to be more understanding, sensitive, and easygoing against the people around them in the context of gender roles. Families teach the boys to be strong, authoritative and tough. Therefore, the boys have more difficulties than the girls in expressing themselves. 
These characteristics can be considered as the reason of the girls' having higher empathic tendencies than the boys.

In this research, resilience was found to be an important predictor of life satisfaction. There are some other studies which express that resilience is an important predictor of life satisfaction (Arslan, Çelebioğlu and Tezel 2008; Kılıç, Yıldız and Kavak 2018). Previous studies show that individuals with good life satisfaction also had high resilience. While resilience is based on the explanation of regenerative elements, such as family and school, in society, regenerative factors play an especially important role in raising individuals with high resilience (Benard 1991; Krovetz 1999). In addition to individual characteristics, internal (familial) and external (environmental) factors are involved in the formation of resilience. Positive conditions, close relationships, and supportive attitudes from family members help create a protective effect on resilience (Beardslee and Podoresky 1988; Gordon and Song 1994). Individuals with a strong social support system are good at coping with stressful life events (Callaghan and Morissey 1993; Shonkoff 1984), and they are better able to overcome psychological problems (Lara, Leader and Klein 1998). They also experience less anxiety and fewer behavioral problems (Barrera, Fleming and Khan 2004).

While students prepare for the university exams in Turkey, their families provide important social support. This can be considered an important factor in strengthening psychological health and increasing ability to rise to challenges. This social support might cause good life satisfaction and resilience and skills of the individuals participated in the research. According to previous studies, social support strengthens both life satisfaction and resilience and there was a strong relationship between these two variables (Goldstein and Brooks 2001; Dayığlu 2008; Savi- Cakar and Karataş 2010). A strong relationship was found between resilience and life satisfaction. Gender is another important variable for resilience (Saka 2017; Çelikkaleli and Kaya 2016). In accordance with the current study, previous literature shows that resilience of girls is higher than boys (Oktan 2008; Dündar 2016). Such a result may be due to factors protect resilience, such as girls' coping with stressors in life and their ability to solve problems better and tendency to ask for help (Yıldırım, Zorbaz, Ulaş, Kızıldağ and Dinçel 2017).

This study also has some limitations. It was carried out at only one university in Turkey. In order to be able to generalize the results, random selections of other universities in Turkey are needed. Based on the findings of this study, it is highly recommended that programs be designed for families and students to provide social gender mainstreaming and that there be an increase in social gender sensitivity, which should include psychoeducation programs. The designation of psychoeducation programs, especially with male students, can make a significant contribution to achieve gender equality. In addition, the designation of programs that include effective coping skills can play an important role in increasing the resilience level of individuals. 


\section{REFERENCES}

Allen, A. B. , Goldwasser , E. R. , \& Leary , M. R. ( 2012 ) Self-compassion and well-being among older adults . Self and Identity, $11,428-453$.

Arıc1, F. (2011). Üniversite öğrencilerinde toplumsal cinsiyet rollerine ilişkin algılar ve psikolojik iyi oluş. [Perceptions of gender roles and psychological well-being among university students.] Yayımlanmamış Yüksek Lisans Tezi. Hacettepe Üniversitesi, Ankara.

Arslan, G. (2015) Yetişkin Psikolojik Sağlamlık Ölçeği'nin (YPSÖ) Psikometrik Özellikleri: Geçerlik ve Güvenirlik Çalışması. Ege Ĕ̆itim Dergisi. 16, (2), 344-357.

Arslan, S., Çelebioğlu, A., Tezel, A. (2008) Kemoterapi alan kanserli hastalarda depresyon ve yaşam doyumunun belirlenmesi. Turkiye Klinikleri Journal of Medical Sciences. 28, 628-34.

Barnard, L. K. \& Curry, J. F. (2012). The relationship of clergy burnout to selfcompassion and other personality dimensions. Pastoral Psychology, 61(2), 149-163.

Barrera, M., Fleming, C. F.,\& Khan, F. S. (2004). The role of emotional social support in the psychological adjustment of siblings of children with cancer. ChildCare Health and Development, 30(2), 103-111.

Beardslee, M. D. ve Podorefsky, M. A. (1988). Resilience adolescents whose parents have serious affective and other psychiatric disorder: Importance of self-understanding and relationships. American Journal of Psychiatry,145, 63-69.

Benard, B. (1991). Fostering resiliency in kids: Protective factors in the family, school and community. Porland: Nortwest Regional Educational Laboratory.

Bhasin, K., 2003. Toplumsal cinsiyet "bize yüklenen roller". Kadınlarla Dayanışma Vakfı Yayınları. İstanbul: Kuşak Ofset Birinci Basım, s.1-5.

Bonanno,G. A. (2004) Loss, trauma, and human resilience: have we underestimated the human capacity to thrive after extremely aversive events? Am. Psychol., 59, 20-28,

Bourgault, P., Lavoie, S., Paul-Savoie, E., Grégoire, M., Michaud, C., Gosselin, E., Johnstone, C.C. (2015). Relationship between empathy and well-being among emergency nurses. J. Emerg. Nurs. 41, 323-328. doi: 10.1016/j.jen.2014.10.001

Buchanan, T., \& Selmon, N. (2008). Race and gender differences in self-efficacy: Assessing the role of gender role attitudes and family background. Sex Roles, 58, 822-836. https://doi.org/dtspph

Cabras, C. Mondo, M. (2018) Coping strategies, optimism, and life satisfaction among first-year university students in Italy: gender and age differences. Higher Education, 75 (4), 643-654.

Caetano S.C., Silva C.M., Vettore M.V(2013) Gender differences in the association of perceived social support and social network with self-rated health status among older adults: a population-based study in Brazil. BMC Geriatr. 13, 122.

Callaghan, P., \& Morrissey, J. (1993). Social support and health: A review. Journal Adv Nurs, 18, 203-210.

Caro, M. M., San-Martín, M., Delgado-Bolton, R., and Vivanco, L. (2017). Empathy, Loneliness, Burnout, and Life Satisfaction in Chilean Nurses of Palliative Care and Homecare Services. Enfermería Clínica (English Edition).

Chen, W., Feng, H., LV, C., LU, J.(2018) Relatıonships between empathy, gender, and testosterone levels in older adults. Social Behavior and Personality, 46 (11), 1895-1908

Choi, D., Minote, N., Sekiya, T., and Watanuki, S. (2016). Relationships between trait empathy and psychological well-being in japanese university students. Psychology 7, 1240. doi: 10.4236/psych.2016.79126

Chui, H., W., Wong, M.,Y., H. (2016) Gender Differences in Happiness and Life Satisfaction Among Adolescents in Hong Kong: Relationships and Self-Concept. Social Indicators Research, 125 (3), 1035-1051. 
Cohn, M.A., Fredrickson, B.L., Brown, S.L., Mikels, J.A., Conway, A.M. (2009) Happiness unpacked: positive emotions increase life satisfaction by building resilience. Emotion, 9, 361-368

Connor, K.M., Davidson J.R. (2003) Development of a new resilience scale: the Connor-Davidson resilience scale (CD-RISC) Depress. Anxiety, 18, 76-82

Cristina Cabras, Marina Mondo (2017) Coping strategies, optimism, and life satisfaction among first-year university students in Italy: gender and age differences. High Education, 75, 643-654. DOI 10.1007/s10734-017-0161-x

Çelikkaleli, Ö. ve Kaya, S. (2016). Üniversite öğrencilerinin cinsiyet ve toplumsal cinsiyet rollerine göre ilişkilerle ilgili bilişsel çarpıtma, psikolojik dayanıklılık ve duygusal yetkinlik inancı. Pagem Eğitim ve Öğretim Dergisi, 6 (2), 187-212.

Dayioglu, B. (2008). Universite giris sinavina hazirlanan adaylarda psikolojik saglamlik: ögrenilmis güçlülük, algilanan sosyal destek ve cinsiyetin rolu [Resilience in university entrance examination applicants: The role of learned resourcefulness, perceived social support, and gender]. (Yayinlanmamis yuksek lisans tezi). Ortadogu Universitesi, Sosyal Bilimler Enstitusu, Ankara.

DiDonato, M. D. and Berenbaum, S. A. (2013) Predictors and consequences of gender typicality: The mediating role of communality. Archives of Sexual Behavior, 42 (3), 429-436, 10.1007/s0508-012-9955-1

De la Fuente-Anuncibay R, Gonza'lezBarbadillo A', Gonza'lez-Bernal J, Cubo E, PizarroRuiz JP (2019) Mediating effect of mindfulness cognition on the development of empathy in a university context. PLoS ONE 14 (4): e0215569. https://doi.org/10.1371/journal. pone.0215569

Diener,E., Oishi,S., Lucas, R.E. (2003) Personality, culture, and subjective well-being: emotional and cognitive evaluations of life. Annu. Rev. Psychol., 54, 403-425.

Dökmen, Ü. (1988). Empatinin yeni bir modele dayanılarak ölçülmesi ve psikodrama ile geliştirilmesi. Ankara Üniversitesi Eğitim Bilimleri Fakültesi Dergisi. 21 (1-2), 155-190.

Dökmen, Z. Y. (2012) Toplumsal Cinsiyet. Sosyal Psikolojik Açıklamalar. 3. Basım. Remzi Kitabevi. İstanbul.

Duru, E. (2002). Öğretmen adaylarında empati-yardım etme eğilimi ilişkisi ve yardım etme eğiliminin bazı psikososyal değişkenler açısından incelenmesi. Pamukkale Üniversitesi Eğitim Fakültesi Dergisi, 2(15).

Dündar, Ü. (2016). Lise öğrencilerinin psikolojik dayanıklılık ve öfke ifade tarzları arasındaki ilişkinin incelenmesi Gaziosmanpaşa İlçesi Örneği. [Examining the relationship between high school students' psychological resilience and anger expression styles, Gaziosmanpaşa district example]. Yüksek Lisans Tezi, Nişantaşı Üniversitesi, İstanbul.

Erçoban, S. (2003). İlköğretim II. kademesindeki branş öğretmenlerinin empatik eğilim düzeylerinin çeşitli değişkenler açısından incelenmesi. [ Examination of the empathic tendency levels of branch teachers at the second level in primary education in terms of various variables.] (Yayınlanmamış yüksek lisans tezi). Uludağ Üniversitesi, Sosyal Bilimler Enstitüsü, Bursa.

Eken, H. (2006). Toplumsal Cinsiyet Olgusu Temelinde Mesleğe İlişkin Rol İle Aile İçi Rol Etkileşimi: Türk Silahlı Kuvvetlerindeki Kadın Subaylar. Selçuk Üniversitesi Sosyal Bilimler Enstitüsü Dergisi, 15, 247-280.

Errasti, J. M., Vázquez, I. A., Villadangos, M. and Morís, J. (2018) Differences between individualist and collectivist cultures in emotional Facebook usage: relationship with empathy, self-esteem, and narcissism. Psicothema, 30, (4), 376-381 doi: 10.7334/psicothema2018.101

Gable, S.L., Haidt, J. (2005) What (and why) is positive psychology? Rev. Gen. Psychol., 9 , pp. 103-110

Glaesmer, H., Grande, G., Braehler, E., Roth, M. (2011) The German version of the satisfaction with life scale (SWLS). Psychometric properties, validity, and population-based norms. European Journal of Psychological Assessment, 27, 127-132, 10.1027/1015-5759/a000058.

Goldbeck, L., Schmitz, T. G., Besier, T., Herschbach, P., \& Henrich, G. (2007). Life satisfaction decreases during adolescence. Quality of Life Research, 16, (6), 969-979. 
Goldsteine, S., \& Brooks, R.B. (2006).Handbook of resilience in children. United States of America: Springer.

Gordon, E. W. ve Song, L. D. (1994). Variations in the experience of resilience. M. C.Wang ve E. W. Gordon (Ed.), Educational resilience in inner-city America: Challenges and prospects. New Jersey: Lawrance Erlbaum Associates Publishers.

Grant-Vallone, E. J., \& Donaldson, S. I. (2001). Consequences of work-family conflict on employee well being over time. Work and Stress, 15, 214-226.

İmamoğlu, E.O. (1994). Değişim sürecinde aile; evlilik ilişkileri bireysel gelişim ve demokratik değerler. Aile Kurultayı. T.C. Başbakanlık Aile Araştırma Kurumu Yayınları

Hu, T., Zhang, D., Wang,J. (2015) A meta-analysis of the trait resilience and mental health. Personal. Individ. Differ., 76, 18-27

Jacobsen, B., Lee, J. B., Marquering, W., \& Zhang, C. Y. (2014). Gender differences in optimism and asset allocation. Journal of Economic Behavior \& Organization, 107, 630-651.

Jenkins J., K. (2016) The relationship between resilience, attachment, and emotional coping styles. Unpublished Master Thesis, Old Dominion University, Norfolk

Kambhampati, U., Guista, M., D., Jewel, S. (2011) Gender and Life Satisfaction in the UK, Feminist Economics, 17, (3), 1-34. Doi: 10.1080/1354701.2011.582028.

Karakaya, D. A. (2001). Akdeniz Üniversitesi'ndeki hemşirelik öğrencilerin empati becerileri. [ Empathy skills of nursing students at Akdeniz University] Yayınlanmamış yüksek lisans tezi. İstanbul Üniversitesi/Sağlık Bilimleri Enstitüsü, İstanbul.

Jolliffe, D., \& Farrington, D. (2006). Development and validation of the Basic Empathy Scale. Journal of Adolescence, 29, (4), 589-611. doi: 10.1016/j.adolescence.2005.08.010.

Keith, P. M. (2007). Barriers and nontraditional students' use of academic and social services. College Student Journal, 41(4), 1123-1128.

Keith, B., Jacqueline, S., 2002. Parent and adolescent gender role attitudes in 1990's Great Britain. Sex Roles 46, (7/8): 239-244.

Kimberly, A., Mahaffy, K., (2002). The gendering of adolescents' childbearing and educational plans: reciprocal effects and the influence of social context. Sex Roles 46(11/12): 403-417.

Kılıç, G., Yıldız, E., Kavak, F.(2018) The relationship between psychological resilience and life satisfaction in COPD patients. Journal of Psychiatric Nursing. 10, (2), 111-116.

Kline, R.B. (2011) Principles and practice of structural equation modeling. Guilford Press, New York.

Krovetz, M. L. (1999). Fostering resiliency expecting all students to use their minds and hearts well. California: Corwin Press.

Lara, M. E., Leader, J., \& Klein, D. N. (1998). What is social support? Harvard Mental Health Letter, 14, (12), 6-8.

Leary, M. R., Tate, E. B. , Adams , C. E. , Allen , A. B. , \& Hancock , J. ( 2007 ) Self-compassion and reactions to unpleasant self-relevant events: the implications of treating oneself kindly . Journal of Personality and Social Psychology, 92, 887 - 904 .

Liu JJW, Reed M, Girard TA.(2017) Advancing resilience: an integrative, multi-system model of resilience. Personality and Individual Differences, 111, 111- 118.

Luthar, S.S. , Cicchetti, D., Becker , B. (2000) The construct of resilience: a critical evaluation and guidelines for future work, Child Dev., 71, 543-562

Mak, W.W., Ng, I.S., Wong, C.C. (2011) Resilience: enhancing well-being through the positive cognitive triad J. Couns. Psychol., 58, 610-617 
Martin, W. E., Swartz-Kulstad, J. L., \& Madson, M. (1999). Psychosocial factors that predict the college adjustment of first-year undergraduate students: implications for college counselors. Journal of College Counseling, 2, (2), 121-133.

Matud, M. P., Bethencourt, J. M., Ibáñez, I. (2014) Relevance of gender roles in life satisfaction in adult people. Personality and Individual Differences. 70, 206-211.

Melman S, Little S. G., Akin-Little K. A. (2007) Adolescent overscheduling: the relationship between levels of participation in scheduled activities and selfreported clinical symptomology. The High School Journal, 18-30.

Moradi, B., \& Subich, L. M. (2002). Feminist identity development measures: Comparing the psychometrics of three instruments. Counseling Psychologist, 30, 66-86.

Myers, J. E., \& Mobley, A. K. (2004). Wellness of undergraduates: comparisons of traditional and nontraditional students. Journal of College Counseling, 7, (1), 40-49.

Mudhovozi, P. (2012). Social and academic adjustment of first year university students. Journal of Social Science, 33(2), 251-259.

Myers, D. G. (2000). The funds, friends, and faith of happy people. American Psychologist, 55, 56-67, 10.1037//003-066x.55.1.56

$\mathrm{Ng}$, Loy, Gudmunson, Cheong (2009). Gender differences in life satisfaction among Chinese Malaysians, Sex Roles, 60, 33-43, 10.1007/s11199-008-9503-6

Neff, K. D. (2009). Self-compassion. In M. R. Leary \& R. H. Hoyle (Ed.), Handbook of Individual Differences in Social Behavior. New York: Guilford Press. pp. 561-573.

Neff , K. D. , Kirkpatrick, K. , \& Rude , S. S. ( 2007 ) Self-compassion and its link to adaptive psychological functioning. Journal of Research in Personality, 41, 139 - 154.

Nickerson, A. B., \& Nagle, R. J. (2004). The influence of parent and peer attachments on life satisfaction in middle childhood and early adolescence. Social Indicators Research, 66, 35-60.

Neff , K. D. , Hsieh , Y. , \& Dejittera , K. ( 2005 ) Self-compassion, achievement goals, and coping with academic failure. Self and Identity, 4, $263-287$.

Oktan, V. (2008). Üniversite sınavına hazırlanan ergenlerin psikolojik sağlamlıklarının çeşitli değişkenlere göre incelenmesi. [ Investigation of psychological resilience of adolescents preparing for university exam according to various variables.]. Doktora Tezi, Karadeniz Teknik Üniversitesi, Trabzon.

Oshio, T. (2012) Gender differences in the associations of life satisfaction with family and social relations among the Japanese elderly. Journal of Cross- Cultural Gerontology, 27, (3), 259-74. doi: 10.1007/s10823012-9169-y.

Parent, M. C., Moradi, B. (2010) Confirmatory factor analysis of the conformity to feminine norms inventory and development of an abbreviated version: The CFNI-45. Psychology of Females Quarterly, 34, 97-109, 10.1111/j.1471-6402.2009.01545.x

Park, C. L., \& Adler, N. E. (2003). Coping style as a predictor of health and well-being across the first year of medical school. Health Psychology, 22(6), 627.

Perrewe, P. L., \& Hochwarter, W. A. (2001). Can we really have it all? The attainment of work and family values. Current Directions in Psychological Science: A Journal of the American Psychological Society, $10,29-33$.

Popham, F., Hunt, K., Benzeval, M., Bhaskar, A., Sweeting H. (2014) Changing gender roles and attitudes and their implications for well-being around the new millennium. Social Psychiatry Psychiatric Epidemiology. 49, (5), 791-809. doi: 10.1007/s00127-013-0730-y 
Preti, A., Vellante, M., Baron-Cohen, S., Zucca, G., Petretto, D. R., \& Masala, C. (2011). The empathy quotient: A cross-cultural comparison of the Italian version. Cognitive Neuropsychiatry, 16, 50-70. https://doi.org/drczxz

Rederstorff, J.C., Buchanan, N.T., Settles, I. H. (2007) The Moderating Roles of Race and Gender-Role Attitudes in the Relationship Between Sexual Harassment and Psychological Well-Being. Psychology of females Quarterly, 31, (1), 50-61.

Rehber, E. ve Atıcı, M. (2009). İlköğretim İkinci Kademe Öğrencilerinin Empatik Eğilim Düzeylerine Göre Çatışma Çözme Davranışlarının İncelenmesi. Çukurova Üniversitesi. Sosyal Bilimler Enstitüsü Dergisi, 18, (1), 323- 342 .

Saka, A. (2017). Farklı aile yapısına sahip ergenlerin öz-yeterlilik ve psikolojik dayanıklılık düzeylerinin incelenmesi. [Investigation of self-efficacy and psychological resilience levels of adolescents with different family structures]. Yüksek Lisans Tezi, Karabük Üniversitesi, Karabük.

Salinas-Jiménez, M.M., Artés, J., Salinas-Jiménez, J. (2013) How do educational attainment and occupational and wage-earner statuses affect life satisfaction? A gender perspective study. Journal of Happiness Studies, 14, 367-388, 10.1007/s10902-012-9334-6.

Savi-Cakar, F., Karatas, Z. (2011). Ergenlerin yilmazlik duzeyleri ile algiladiklari sosyal destek arasindaki iliski [The relationship between the resilience level of adolescents and perceived social support]. Cagdas Egitim Dergisi, 36, (387), 12- 20.

Sayın, K. B. (2010). İlköğretim birinci kademe öğrencilerinin empati becerileri ile anne baba tutumları arasındaki ilişki. [The relationship between empathy skills and parental attitudes of primary school students.]. Yayınlanmamış Yüksek Lisans Tezi, Maltepe Üniversitesi Sosyal Bilimler Enstitüsü, İstanbul.

Schuetze, H. G., \& Slowey, M. (2002). Participation and exclusion: a comparative analysis of non-traditional students and lifelong learners in higher education. Higher Education, 44, (3-4), 309-327.

Shonkoff, J. P. (1984). Social support and the development of vulnerable children. Am. Journal Public Health, $74,(4), 310-312$.

Skinner, E. A., \& Zimmer-Gembeck, M. J. (2007). The development of coping. Annual Review of Psychology, 58, $119-144$.

Solak, N. (2011). Spor yapan ve yapmayan ortaöğretim öğrencilerinin saldırganlık düzeyleri ile empatik eğilim düzeyleri arasındaki ilişkinin incelenmesi- Çorum ili örneği. [Investigation of the Relationship Between Aggression Levels and Empathic Tendency Levels of Secondary School Students Who Play and Don't Do Sports- The Case of Çorum Province]. Yayımlanmamış yüksek lisans tezi. Gazi Üniversitesi/Eğitim Bilimleri Enstitüsü, Ankara.

Spreng RN, McKinnon MC, Mar RA, Levine B. (2009) The Toronto Empathy Questionnaire: Scale development and initial validation of a factor-analytic solution to multiple empathy measures. Journal of personality assessment. 91, (1), 62-71. https://doi.org/10.1080/00223890802484381 PMID: 19085285

Staggenborg, S., 1998. Gender, family and social movements. California: Pine Forge Press, p.1-3.

Terri, H., Chan, M. (2014). Facebook and its effects on users' empathic social skills and life satisfaction: A double-edged sword effect. Cyberpsychology, behavior, and social networking, 17, (5), DOI: 10.1089/cyber.2013.0466

Tepeli-Temiz, Z., Tari- Cömert, I.(2018) The Relationship Between Life Satisfaction, Attachment Styles, and Psychological Resilience in University Students. The Journal of Psychiatry and Neurological Sciences, 31, 274-283. DOI: 10.5350/DAJPN2018310305

Trommsdorff, G., Iwawaki, S., 1989. Student's perceptions of socialisation and gender role in Japan and Germany. International Journal of Behavioral Development 12, (4), 485- 493.

Quimby, J. L., \& O'Brien, K. M. (2006). Predictors of well-being among nontraditional female students with children. Journal of Counseling \& Development, 84, (4), 451-460. 
Uchino, B. N., Cacioppo, J. T., \& Kiecolt-Glaser, J. K. (1996). The relationship between social support and physiological processes: A review with emphasis on underlying mechanisms and implications for health. Psychological Bulletin, 119, 488-531.

Ünsal-Barlas, G., Karaca, S., Onan, N., Işı1, Ö. (2010) The Relationship between Self-Perception and Psychiatric Symptoms in a Group of Students Preparing for the University Entrance Examination. Journal of Psychiatric Nurses, 1, (1):18-24.

Yau, H. K., \& Cheng, A. L. F. (2014). An empirical study into gender differences in the relationships among academic, social and psychological adjustments of university support. Journal of Further and Higher Education, 38, (2), 268-282.

Van de Vijver, F. J. R. (2007). Cultural and gender differences in gender-role beliefs, sharing household task and child-care responsibilities, and well-being among immigrants and majority members in the Netherlands. Sex Roles, 57, 813-824. https://doi.org/dsnjdq

Yıldırım, İ., Zorbaz, D. S., Ulaş, Ö., Kızıldağ, S., Dinçel, E. F. (2017). Akademik Başarısı Düşük Ve Yüksek Olan Üniversite Öğrencilerinin Nitelikleri. Kastamonu Eğitim Dergisi, 25, (6), 2190-2214.

Yongxia, G.(2019) Gender role attitudes and their psychological effects on Chinese youth. Social Behavior and Personality, 47, (5), e7563 https://doi.org/10.2224/sbp.7563 www.sbp-journal.com

Wasylkiw, L. , Mackinnon, A. L. , \& Maclellan, A. M. ( 2012 ) Exploring the link between self-compassion and body image in university females. Body Image, 9, 236- 245.

Zhang, M., Zhang, J., Zhang, F., Zhang, L., Feng, D. (2018) Prevalence of psychological distress and the effects of resilience and perceived social support among Chinese college students: Does gender make a difference? Psychiatry Research, 267, 409-413. 